\begin{tabular}{|l|l|l||}
\hline \multicolumn{2}{|c|}{ PublisherInfo } \\
\hline \hline PublisherName & $:$ & BioMed Central \\
\hline \hline PublisherLocation & $:$ & London \\
\hline \hline PublisherImprintName & $:$ & BioMed Central \\
\hline \hline
\end{tabular}

\title{
PAC-p53 interactions
}

\begin{tabular}{|l|l|l||}
\hline \multicolumn{2}{|c|}{ ArticleInfo } \\
\hline \hline ArticleID & $:$ & 4740 \\
\hline \hline ArticleDOI & $:$ & $10.1186 /$ gb-spotlight-20030403-01 \\
\hline \hline ArticleCitationID & $:$ & spotlight-20030403-01 \\
\hline \hline ArticleSequenceNumber & $:$ & 92 \\
\hline \hline ArticleCategory & $:$ & Research news \\
\hline ArticleFirstPage & $:$ & 1 \\
\hline \hline ArticleLastPage & $:$ & 2 \\
\hline \hline & & RegistrationDate : 2003-4-3 \\
\hline ArticleHistory & $:$ & OnlineDate \\
\hline \hline ArticleCopyright & $:$ & BioMed Central Ltd2003-4-3 \\
\hline \hline ArticleGrants & $:$ & \\
\hline \hline ArticleContext & $:$ & 130594411 \\
\hline \hline
\end{tabular}




\section{Tudor P Toma}

Email: t.toma@imperial.ac.uk

The tumor suppressor protein $\mathrm{p} 53$ has a role in cellular apoptosis through the transcriptional regulation of several target genes, including PAC1 (phosphatase of activated cells 1) which inactivates mitogen-activated protein (MAP) kinases. However, the molecular mechanisms of interaction between p53 and PAC1 have been unclear. In the April 3 Nature, Yuxin Yin and colleagues at Columbia University, New York, show that under specific stress conditions, p53 regulates transcription of PAC1 through a novel p53-binding site, and that PAC1 is necessary and sufficient for p53-mediated apoptosis (Nature, 422:527-531, April 3, 2003).

Yin et al. used a p53-inducible system comprising EB-1 cells derived from a human colon cancer with mutant p53. They observed that PAC1 transcription was induced in these cells in response to serum deprivation and oxidative stress, resulting in p53-dependent apoptosis. Using small interfering RNA they reduced PAC1 transcription and observed an inhibition of p53-mediated apoptosis. Overexpression of PAC1 increased susceptibility to apoptosis and suppressed tumor formation. In addition, they showed that activation of $\mathrm{p} 53$ significantly inhibits MAP kinase activity.

"We demonstrate here that p53 uses a palindromic binding site to regulate its target gene PAC1. The identification of this mechanism for $\mathrm{p} 53$ action will provide insights into the molecular basis of how p53 selectively regulates its target genes to eliminate cancer cells and suppress tumorigenesis", conclude the authors.

\section{References}

1. Surfing the p53 network.

2. Nature, [http://www.nature.com/]

3. Columbia University, [http://www.columbia.edu/] 